\title{
Synthesis and Biological Properties of Silver Chloride Nanoparticles Using Cell-free Extracts of Aeromonas hydrophila and Antibacterial Activity against Drug-Resistant Bacteria
}

\author{
Azadeh Hadad Sabzevar ${ }^{1}$ \\ http://orcid.org/0000-0002-9544-2703 \\ Gholam Reza Hashemitabar ${ }^{1 *}$ \\ http://orcid.org/0000-0001-9760-1096 \\ Mehrnaz Rad ${ }^{1}$ \\ http://orcid.org/0000-0001-7150-5178 \\ Jafar Vatandoost ${ }^{2}$ \\ http://orcid.org/0000-0001-5161-5863
}

${ }^{1}$ Ferdowsi University of Mashhad, School of Veterinary Medicine, Department of Pathobiology, Mashhad, Iran; ${ }^{2}$ Hakim Sabzevari University, Faculty of Sciences, Department of Biology, Sabzevar, Iran.

Editor-in-Chief: Alexandre Rasi Aoki

Associate Editor: Fábio André dos Santos

Received: 2021.01.09; Accepted: 2021.05.05.

Correspondence: hashemit@um.ac.ir; Tel: 05138805650. (G.R.H.).

\section{HIGHLIGHTS}

- Evaluation of a new method for preparing bacterial cell-free extract to develop a simple, costeffective, biocompatible and environmental approach

- $\mathrm{NADH}$-dependent nitrate reductase enzyme is present as the most important factor for silver ion reduction and silver nanoparticle production.

- There is a significant difference between the antioxidant activity of nanoparticles compared to the extract.

- Biosynthesized nanoparticles have a stronger antibacterial potential than drug-resistant bacteria.

- Biosynthesized nanoparticles have cytotoxic effects in some human cell lines (breast cell line (MCF-7) and liver cancer (HepG-2).

Abstract: Microorganisms have been studied as potential biological factories for the synthesis of silver nanoparticles. In the present study, the cell-free extract of Aeromonas hydrophila was used to synthesize silver nanoparticles because the extract has a dual role in reducing and stabilizing silver nanoparticles. In this study, silver nanoparticles were synthesized using Aeromonas hydrophila. Synthetic nanoparticles were examined using ultraviolet-visible spectroscopy, X-ray diffraction, Fourier transform infrared (FT-IR), 
transmission electron microscopy (TEM) and X-ray diffraction (EDX) spectroscopy. In this study, antimicrobial properties of Staphylococcus aureus, Bacillus subtilis, Escherichia coli and Pseudomonas aeruginosa and anti-cancer properties (MCF-7, HepG-2) of silver nanoparticles were investigated. The synthesis of silver nanoparticles was confirmed by ultraviolet-visible spectroscopy and X-ray diffraction. TEM images detected the spherical shape of nanoparticles of various sizes in the range of 1-20 nm. FT-IR analysis demonstrated that enzyme, protein and carbohydrate compounds can be proven as stabilizing agents on the surface of silver nanoparticles. The resulting nanoparticles had strong antibacterial activity against drug-resistant bacteria. Silver chloride nanoparticles were also toxic to MCF-7 and HepG-2 cancer cells. The green synthesis method is cost-effective, environmentally friendly and an easy alternative to conventional silver nanoparticle synthesis methods.

Keywords: Silver nanoparticles; green synthesis; Aeromonas hydrophila; antimicrobial activity.

\section{INTRODUCTION}

Nanoparticles are defined as particles in the size range of $1-100 \mathrm{~nm}$ that have unique chemical and physical properties such as high surface to volume ratio in comparison with their bulk materials [1]. One of the most important and widely used nanoparticles is silver nanoparticle. Silver nanoparticles have been considered by researchers due to their wide application in various scientific fields such as circuits, tracking in biological systems, sensors, filters, antibacterial fibers, electrochemical electrodes and antimicrobial properties [2]. Monovalent silver compounds have been widely used for decades to treat bacterial infections, and studies have shown that silver nanoparticles also have these properties [3]. Special methods have been developed for the synthesis of silver nanoparticles. Physical and chemical techniques are able to produce large amounts of nanoparticles of a certain size and shape in a relatively short time, but are complex, costly and inefficient and produce hazardous toxic wastes that are harmful [4]. Among the green methods of nanoparticle production, biological methods are suitable alternatives for making nanoparticles that are costeffective and environmentally friendly. In this method, the extracts obtained from biological organisms (including plants, algae and microorganisms) are used as both stabilizing and reducing agents to make nanoparticles. Among biological organisms, bacteria have been considered more than other microorganisms due to their ease of use and the possibility of genetic manipulation [5].

The microbial synthesis of metal nanoparticles can be intracellular or extracellular [6]. The intracellular synthesis of nanoparticles requires appropriate methods for cell lysis [7] while the extracellular biosynthesis is cheaper and easier [8]. For this reason, in many studies, the biosynthesis of nanoparticles has been done extracellularly so that the researchers could produce silver and gold nanoparticles using culture supernatant of various bacteria such as Escherichia coli and Sporosarcina koreensis $[9,10]$.

The culture medium may contain reducing agents such as yeast extract and tryptone. These compounds can synthesize AgNP without the need for bacteria. The nanoparticles produced by this method are surrounded by organic compounds of the culture medium. As a result, the dispersion, recovery and properties of the nanoparticle are disrupted, which prevents the use of the nanoparticle in its normal applications. Considering the problems in the fabrication of nanoparticles using bacterial culture supernatant, an alternative method for extracellular production of nanoparticles is the use of bacterial cell-free extracts [11]. This study aimed to investigate a new method for the preparation of a bacterial cell-free extract to develop a simple, cost-effective, biocompatible and environmental approach for the extracellular biological synthesis of AgNPs using Aeromonas hydrophila and the evaluation of the antibacterial activity of synthesized AgNPs against $S$. aureus, $B$. subtilis, E. coli and $P$. Aeruginosa.

\section{MATERIAIS AND METHODS}

\section{Materials and microorganisms}

$\mathrm{AgNO}_{3}$, glucose, potassium nitrate, Propanol, Sodium nitrite, sulfanilamide, $\mathrm{HCl}$, ethylene dihydrochloride dihydrochloride, ethanol, Phosphoric acid, acetone, ninhidrine, potassium cyanide, Glycine, Citrate buffer, sulfuric acid, DPPH, comassi brent blue, Albumin serum bovine and phenol blue were purchased from Sigma Aldrich (St. Louis, MO, USA) and Mueller-Hinton agar, Mueller-Hinton broth and LB were purchased from Merck Millipore Company (Germany). Multidrug-resistant bacteria, including Staphylococcus aureus (ATCC 25923), Bacillus subtilis (ATCC 6633), Escherichia coli (ATCC 25922) and Pseudomonas aeruginosa (ATCC27853), were used to show antimicrobial activity of silver nanoparticles. 
These strains were obtained from the laboratory of Tehran Pasteur Institute. For further evaluation, bacterial strains of nutrient agar slant were kept at $4^{\circ} \mathrm{C}$.

\section{Bacterial strain and growth conditions}

To prepare the bacterial cell-free extract, the standard strain of Aeromonas hydrophila (IBRC-M 10814) obtained from Iran Genetic Resources Center was used. To isolate maximum nitrate reductase (NR), LB medium was used by adding glucose $(15 \mathrm{~g} / \mathrm{mL})$ and potassium nitrate $(3.5 \mathrm{~g} / \mathrm{ml})$. This culture was incubated in a shaker at $150 \mathrm{rpm}$ at $37^{\circ} \mathrm{C}$. Each bacterial culture was centrifuged after 18 hours in the logarithmic growth stage (12000 rpm, 20 minutes, $4^{\circ} \mathrm{C}$ ). The supernatant was discarded and $1 \mathrm{~g}$ of bacterial biomass was suspended in $10 \mathrm{ml}$ of sterile distilled water and was centrifuged after 72 hours of incubation $\left(37^{\circ} \mathrm{C}\right.$, $12000 \mathrm{rpm})$. Bacterial cell-free extract adjusted to $\mathrm{pH} 11$ to $1 \mathrm{mM}$ final concentration of AgNO3 was placed in the dark at room temperature. The color changes of each sample were periodically examined by UV-Vis spectroscopy. $\mathrm{AgNO}_{3}(1 \mathrm{mM})$ and bacterial cell-free supernatant were used as controls and were kept under the same conditions.

\section{Optimization of silver nanoparticle synthesis}

The bioproduction of silver nanoparticles was investigated and compared in terms of the impact of different parameters on the reaction. These factors include $\mathrm{pH}$ (6-12), different concentrations of AgNO3 $(1,3,5,10 \mathrm{mM})$ and temperature (25-60-80). All factors were tested sequentially and the result of each experiment was performed in the next experiment. The results were analyzed by UV-Vis spectroscopy.

\section{Evaluation and characterization of synthesized nanoparticles}

Reduction of silver ions by measuring the UV-Vis spectrum (Analytic Jena Spectrophotometer, German) of the reaction medium was examined at different time intervals through diluting a small amount (100 $\mu$ l) of the sample 10 times in deionized water. UV-Vis spectroscopic analysis was performed by continuous scanning from $300 \mathrm{~nm}$ to $700 \mathrm{~nm}$ and $1 \mathrm{mM}$ AgNO3 solution was used for the blank. Characterization of AgNPs was performed by X-ray diffractometer (Philips PW1730) with a voltage of $40 \mathrm{kV}$ and a current of 30 $\mathrm{mA}$ with $\mathrm{Cu}$ Ka radiation at position $2^{\theta}$. The amount of the crystal amplitude of the width of the XRD peak is calculated using the Scherrer formula, assuming that they are of non-uniform types:

$$
D=0.94 \lambda / \beta \cos \theta
$$

In which, $D$ is the crystal mean size perpendicular to the reflective plates, $\lambda$ is the $X$-ray wavelength, $\beta$ is the full width half maximum (FWHM) and the diffraction angle [12]. To evaluate the morphology of the size of the synthesized silver nanoparticles, imaging was performed with a transmission electron microscope. The nanoparticle powder sample was ultrasonized for 15 minutes and was placed on a grid with carbon film. After cooling the grid without dry heat and in the vicinity of room air, imaging was performed using Philips transmission electron microscope.

In order to determine the functional groups in the synthesized nanoparticles, FT-IR spectroscopy was used as a suitable analytical method. FT-IR was measured by Thermo AVATAR spectrometers (America). FT-IR spectrum of dried nanoparticle samples in the infrared spectrum (4000 cm- ${ }^{1}$ to $\left.400 \mathrm{~cm}^{-1}\right)$ with a resolution of $4 \mathrm{~cm}^{-1}$ was examined in the absorption state of $10-120$ scans at a temperature of $25^{\circ} \mathrm{C}$.

\section{Determination of bacterial extract reducing agents}

\section{NR enzyme test}

Nitrate reductase converts nitrate to nitrite. According to Harley's method [13], by placing the enzyme substrate (nitrate) and then measuring the amount of nitrite after 1 hour, the enzyme activity was determined. An increase in pure nitrite in 1 hour indicates the level of nitrate reductase activity. Reagents are as follows: Assay medium: $30 \mathrm{mM} \mathrm{KNO}_{3}$ and $5 \%$ propanol in $0.1 \mathrm{M}$ phosphate buffer $\mathrm{pH} 7.5$; nitrite solution: $25 \mu \mathrm{M}$ NaNO2 solution (nitrite); nitrite assay reagents: Sulfanilamide solution: $1 \%(\mathrm{w} / \mathrm{v})$ in $25 \%(\mathrm{v} / \mathrm{v})$ hydrochloride and $0.02 \%(\mathrm{w} / \mathrm{v})$ ethylenediamine dihydrochloride solution (NEED) in distilled water. Five tubes, each containing $2 \mathrm{ml}$ of Aeromonas hydrophila culture supernatant, were prepared from the $72 \mathrm{~h}$ reaction. Tubes "a" and "b" (two replicates) were placed in a boiling water bath to kill the enzyme as soon as assay medium of $2 \mathrm{~mL}$ enzyme was added. After boiling for 5 minutes, the tubes were kept at room temperature to measure nitrite. $2 \mathrm{~mL}$ of the assay medium was added to tubes $\mathrm{c}, \mathrm{d}$ and e (three replicates) and was kept in the dark 
for 60 minutes before placing the tubes in the boiling water bath. After cooling the samples, $1 \mathrm{~mL}$ of sulfanilamide solution was added to each. Then, $1 \mathrm{~mL}$ of NEED solution was added and mixed quickly by inverting the tubes. After 20 minutes, the absorbance rate at $540 \mathrm{~nm}$ was measured using German Analytic Jena spectroscopy. The nitrite content in tubes "a" and "b" is deducted from the nitrite content in tubes c, $d$ and e to calculate the amount produced by enzyme activity during 60 minutes. The standard sodium nitrite curve was prepared by inserting known amounts of nitrite ( 0 to $250 \mathrm{nmol} \mathrm{NO}$ ) and after that by $1 \mathrm{~mL}$ of sulfanilamide and $1 \mathrm{~mL}$ of NEED solution. After mixing and incubation for 20 minutes at room temperature, the absorption was measured at $540 \mathrm{~nm}$. Enzyme activity was calculated based on the increase in nitrite for more than 60 minutes for a sample amount of $2 \mathrm{~mL}$ and was expressed as nmol nitrite/h/mL [14].

\section{Protein concentration assay}

Protein concentration in the bacterial extract was determined by Bradford method [15]. Bradford reagent containing comassi brent blue G-250 and ethanol and phosphoric acid with final concentrations of $0.01,4.7$ and $8.5 \%(\mathrm{~W} / \mathrm{V})$ were prepared, respectively. This protein was red reactant and after combining with the protein, its color changed to blue and the maximum absorption was read at $595 \mathrm{~nm} .1 \mathrm{mg} / \mathrm{mL}$ bovine serum albumin is used as the standard protein. About $100 \mu \mathrm{L}$ of different concentrations of BSA $(0.1-1 \mathrm{mg})$ of the bacterial extract was prepared in test tubes and $5 \mathrm{~mL}$ of Bradford reagent was added to each concentration and then, pipetting and mixture absorption were measured at $595 \mathrm{~nm}$ after 2 minutes.

\section{Amino acid content assay}

Amino acid content in the bacterial extract was determined by the ninhydrin method [16]. The test medium of ninhydrin consists of two parts; A: $5 \%$ ninhydrin in acetone and B: $1 \mathrm{ml}$ of potassium cyanide $(0.01$ $\mathrm{mM}$ in ethanol $60 \% \mathrm{v} / \mathrm{v}$ ) which reached a volume of $50 \mathrm{~mL}$ by acetone. To prepare ninhydrin acetone $\mathrm{KCN}$ medium, $10 \mathrm{~mL}$ of solution A was diluted by $50 \mathrm{~mL}$ of solution $B$. An amount of $1-100 \mu \mathrm{g} / \mathrm{mL}$ glycine in citrate buffer $(0.2 \mathrm{M}, \mathrm{pH}=5)$ was prepared as a standard curve solution. $2 \mathrm{~mL}$ of each dilution of glycine and bacterial extract was combined with $1 \mathrm{~mL}$ of ninhydrin reagent. The resulting solution was mixed well and placed in a boiling water bath for 20 minutes. After cooling the tubes, the volume of each tube was increased to $10 \mathrm{~mL}$ with water and its absorbance was read at $570 \mathrm{~nm}$. According to the standard curve line equation, the amino acid concentration in the bacterium was determined based on $\mu \mathrm{g} / \mathrm{mL}$.

\section{Carbohydrate content assay}

In order to measure carbohydrate content (including monosaccharide, oligosaccharide and polysaccharide) in the bacterial extract, phenol sulfuric acid method was performed [17]. Carbohydrates produce furfural derivatives in a reaction mixture with $97 \%$ sulfuric acid. Furfural can react with phenol to form a molecule with a maximum absorption of $490 \mathrm{~nm}$. Glucose solution with a concentration of $10-70 \mu \mathrm{g} / \mathrm{mL}$ was used for the standard curve. A volume of $200 \mu \mathrm{L}$ of $5 \%$ aqueous phenol solution (W/V) was added to $400 \mu \mathrm{L}$ of bacterial extract. Then, $1 \mathrm{~mL}$ of sulfuric acid was immediately added to the mixture and was kept at room temperature for 10 minutes. The samples were vortexed for 30 seconds and the absorbance was recorded at $490 \mathrm{~nm}$ after 20 minutes.

\section{Characteristics of DPPH radical scavenging}

The free radical scavenging capacity of the bacterial extract was measured by 1-1 diphenyl-2-picryl hydrazyl method [18]. DPPH is a stable free radical with missing electron that, when dissolved in methanol or ethanol, turns violet and has a maximum absorption of about $517 \mathrm{~nm}$. When DPPH is released into a component, hydrogen changes its color to yellow and thus absorption is reduced to $517 \mathrm{~nm}$. Different volumes of bacterial extract and nanoparticle $(100-500 \mu \mathrm{g}$ in methanol) were mixed with $1 \mathrm{~mL}$ of freshly made methanolic solution of DPPH radical $(80 \mu \mathrm{g} / \mathrm{mL})$ and were kept in ice for one hour in the dark. The absorbance was then read at $517 \mathrm{~nm}$. In this experiment, methanol was used as the blank and a mixture of methanol and DPPH solution without the test sample was used as a control sample. The ability of samples in DPPH radical scavenge is demonstrated by the following formula:

$$
D P P H \text { scavenging effect }=\frac{\text { Control OD-Sample OD }}{\text { Control OD }} \times 100
$$




\section{Determination of released silver ions}

To remove reaction-free $\mathrm{Ag}^{+}$ions from the nanoparticle sample, $\mathrm{NaCl}$ solution was used. After the addition of $\mathrm{NaCl}, \mathrm{Ag}^{+}$reacts with $\mathrm{Cl}^{-}$to form a white precipitate of $\mathrm{AgCl}$. The precipitate was then removed by centrifugation at $4000 \mathrm{rpm}$ for 15 minutes. After removal of the precipitate, the supernatant was centrifuged at $14000 \mathrm{rpm}$ for 30 minutes to concentrate the silver nanoparticles concentration and then, they were dried at $50^{\circ} \mathrm{C}$. After that, their dry weight was estimated. For further study, silver nanoparticles were resuspended in deionized water to achieve their desired concentration [19].

Disruption of silver nanoparticles was performed with an ultrasonic processor (Sonics Vibra Cell VC$505 / 220$, Newtown, USA) over three periods of 15 seconds with an interval of 45 seconds between periods. Then, ultrasonic samples were taken and the resulting solution was filtered through a $0.22 \mathrm{~mm}$ filter (Millipore).

\section{Antimicrobial activity of AgNP}

Antibacterial activity of AgNPs was examined by agar well diffusion method against Staphylococcus aureus (ATCC 25923), Bacillus subtilis (ATCC 6633), Escherichia coli (ATCC 25922) and Pseudomonas aeruginosa (ATCC 27853). Bacteria were spread with $0.5 \mathrm{McFarland}$ turbidity in Müller-Hinton (MH) agar medium. $6 \mathrm{~mm}$ diameter agar wells were prepared and loaded with $50 \mu \mathrm{L}$ of Ag NPs solution from dilutions of $100,50,25,12.5,6.25$ and $50 \mu \mathrm{L}$ of AgNO3-free bacterial cell suspension as a control. The plates were incubated at $37^{\circ} \mathrm{C}$ for 24 hours and the diameter of the inhibition zone was measured as shown by the clear zone without growth of the experimental strains. Each experiment was performed in three replications [20].

\section{Determination of minimum inhibitory concentration (MIC) of AgNPs}

The MIC of AgNPs was determined using microplate dilution method [16]. $100 \mu \mathrm{L}$ of broth culture solution was added to each well and $100 \mu \mathrm{L}$ of AgNP from dilutions of 100, 50, 25, 12.5, 6.25, 3.125 and $1.56 \mu \mathrm{L} / \mathrm{mL}$ of the nanoparticle were added to 96-well plates. Four bacterial strains including Staphylococcus aureus (ATCC 25923), Bacillus subtilis (ATCC 6633), Escherichia coli (ATCC 25922) and Pseudomonas aeruginosa (ATCC 27853) with the amount of $10^{5} \times 5 \mathrm{CFU} / \mathrm{mL}$ were incubated for 18 to 24 hours at $37^{\circ} \mathrm{C}$. Bacterial suspension culture medium was used as positive control and culture medium and the nanoparticle were used as negative control. Optical density at $600 \mathrm{~nm}$ (OD600) was used to estimate the bacterial population concentration. The well whose turbidity was clearer due to lack of bacterial growth was also reported as MIC of nanoparticles.

\section{Determining cell viability}

3-(4 5-dimethylthiazol-2 yl)-2 5-diphenyltetrazolium bromide (MTT) was used to determine live cells after treatment. This is a competitive mitochondrial metabolic test that demonstrates the function of mitochondrial dehydrogenase enzyme in Tetrazolium decomposition by living cells [21]. Reductase enzymes in living cells, especially those that are NADH-dependent in mitochondria, reduce MTT to insoluble formazan crystals which are soluble in dimethyl sulfoxide (DMSO) with a maximum absorption at $570 \mathrm{~nm}$. Liver cancer cell (HepG-2) and breast cancer cell (Mcf-7) lines were cultured in DMEM (Dulbecco's Modified Eagle Medium) with 10\% fetal PBS and $1 \%$ antibiotics (penicillin and streptomycin) at $37{ }^{\circ} \mathrm{C}$ in the presence of $5 \%$ carbon dioxide (CO2). The number of each cell type was counted by neubauer slide and $2 \times 10^{4}$ cells from each cell line were cultured in 96-well microplates and the culture medium was added to a final volume of up to $100 \mu \mathrm{l}$ per well. To investigate the effect of NP on cell growth, $100 \mu \mathrm{L}$ of nanoparticles diluted by culture medium from dilutions of $100,50,25,12.5,6.25,3.125$ and $1.56 \mu \mathrm{L} / \mathrm{mL}$ of the nanoparticle were added to each well and were incubated in the presence of $5 \% \mathrm{CO} 2$. The culture medium in each well was discarded after 24 hours. MTT solution ( $1 \mathrm{mg} / \mathrm{ml})$ in phosphate-containing salt ( $\mathrm{pH} \mathrm{4.7)}$ with culture medium was added $(0.5 \mathrm{mg} / \mathrm{mL}$ and 200 $\mu \mathrm{l}$ of it) to each well and was incubated for 2-4 hours. Formazan crystals were dissolved in $100 \mu \mathrm{L}$ of DMSO. After 30 minutes of incubation and ensuring that the paint particles dissolved, the light absorption of the wells was read at $570 \mathrm{~nm}$ using an ELISA reader. The concentration that inhibited cell growth up to $50 \%$ was considered as IC50. Cell survival percentage was calculated according to the following formula:

Cell survival rate $=($ treated sample OD $/$ control OD $) \times 100 \%$ 


\section{Data analysis}

Statistical analysis was performed using SPSS-16 software (SPSS Inc., Chicago, IL, USA) and the results were evaluated by one-way ANOVA (Tukey's test). Further, all experiments were performed in three replications and the mean of standard errors was calculated and $p<0.05$ was considered statistically significant.

\section{RESULTS AND DISCUSSION}

AgNPs were synthesized with AgNO3 using cell-free extract of Aeromonas hydrophila. The formation of Ag-NPs in colloidal solution was investigated using UV-Vis spectral analysis. Brown color changes show AgNP synthesis with a maximum absorption of $380-450 \mathrm{~nm}$, which is due to surface plasmon resonance (SPR). This phenomenon is related to the energy equivalence between the conductive electrons in the last metal layer and the energy of the electromagnetic waves emitted to the nanoparticles. The SPR peak in AgNP depends on its size, shape and environment. Sufficient amounts of AgNP can be obtained by using a suitable growth medium, synthesis conditions, $\mathrm{pH}$, substrate concentration, temperature and reaction time [22]. On the other hand, reduction of silver ions did not occur in the absence of bacterial cells. This clearly shows that the reducing agents released in the bacterial supernatant play a role in reducing silver.

\section{Optimization of AgNP synthesis}

Optimization of important factors in nanoparticle synthesis can control the morphology and other properties of nanoparticles. Conditions such as $\mathrm{pH}$, temperature and AgNO3 concentration affect the size and shape of nanoparticles. $\mathrm{pH}$ is one of the most important factors in the formation of nanoparticles. The shape and size of the nanoparticles depend on the solution $\mathrm{pH} . \mathrm{pH}$ has the ability to change the loads of biological molecules, which can affect their coating as well as the ability to stabilize. To investigate the effect of $\mathrm{pH}$ on the formation of silver nanoparticles, solutions of the bacterial extract were prepared at different $\mathrm{pHs}$ (6-12) (Figure 1a). With a gradual increase in the solution $\mathrm{pH}$ to 10 , the absorption of the solution has increased dramatically, which is related to the increase in the amount of silver nanoparticles synthesis. At pH 10 , the absorption peak changed from $450 \mathrm{~nm}$ to $430 \mathrm{~nm}$. This decrease in the absorption spectrum indicates a decrease in AgNP size. With increasing pH to 12, we see a decrease in absorption due to the instability of silver nanoparticles or the lack of a stabilizing agent. In order to investigate the effect of silver nitrate concentration on the formation of silver nanoparticles, solutions of the bacterial extract were prepared in different concentrations of silver nitrate $(1,3,5,10 \mathrm{mM})$. The effect of metal ion concentration on nanoparticle synthesis is shown in Figure (1b). As observed previously, in $1 \mathrm{mM}$ solution of silver nitrate, the rate of nanoparticle formation is higher than other concentrations. Therefore, in subsequent experiments, this concentration was considered as the optimal concentration. Figure (1c) displayed that at 60 and $80^{\circ} \mathrm{C}$, nanoparticle formation is higher than other temperatures. Considering that there was no significant difference between the two temperatures, $60^{\circ}$ was chosen as the optimal temperature. So, the final concentration of 1 $\mathrm{mM}$ and $\mathrm{pH} 10$ and temperature of $60 \mathrm{~b}{ }^{\circ} \mathrm{C}$ were selected as the best conditions for the synthesis of silver nanoparticles. According to Mie theory, spherical nanoparticles have a SPR peak while asymmetric particles and different forms with one or more shoulder are at their SPR peak [23]. Therefore, the presence of a single SPR peak indicates spherical AgNPs [24].
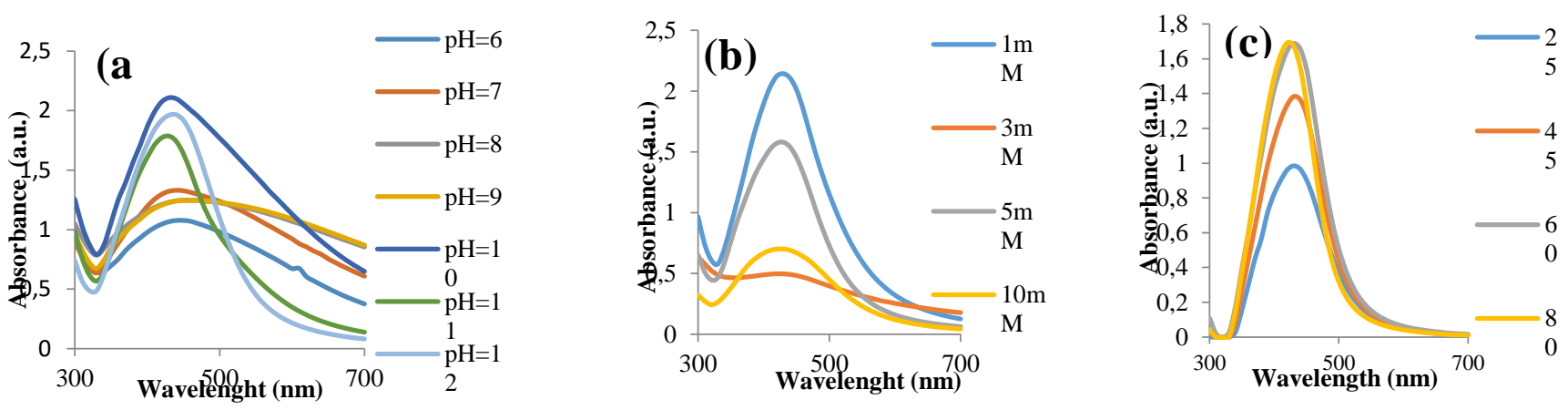

Figure 1. Absorption spectra of silver nanoparticles; 2a: Absorption spectra of silver nanoparticles at different pH values $(\mathrm{pH} 5,6,7,8,9,10,11,12)$ of the reaction mixture; 2b: Absorption spectra of silver nanoparticles at various concentrations of silver salt $(1,2,3,5,10 \mathrm{mM})$; 2c: Absorption spectra of silver nanoparticles obtained at different reaction temperatures of $25,45,60$ and $80^{\circ} \mathrm{C}$. 


\section{Study of silver nanoparticle properties}

\section{Study of the structure of silver nanoparticles with XRD}

The crystalline nature of silver nanoparticles was confirmed by XRD pattern analysis (Figure 2a). This figure shows the peaks in values of $2^{\theta}, 28.05,32.43,46.54,55.07,57.66,67.70,74.80$ and 76.97 according to plates (111), (200), (220), (311), (222), (400), (331) and (420) of Bragg reflection and their comparison with the standard pattern of silver chloride with the code JCPDS. 00-006-0480. It is displayed that compared to the produced nanoparticle, the nanoparticle is made of silver chloride. Peak 200 is more intense than other peaks, so the crystal plates of silver nanoparticles are more formed in this direction. The average size of the synthesized crystalline particles was estimated by calculating Debye-Scherrer formula of $24 \mathrm{~nm}$. The difference in size reported by transmission electron microscopy (TEM) may be due to the preparation steps. The results obtained by Paulkumar and coauthors [16,25] and Somee and coauthors [16] were consistent with our findings.

(a)

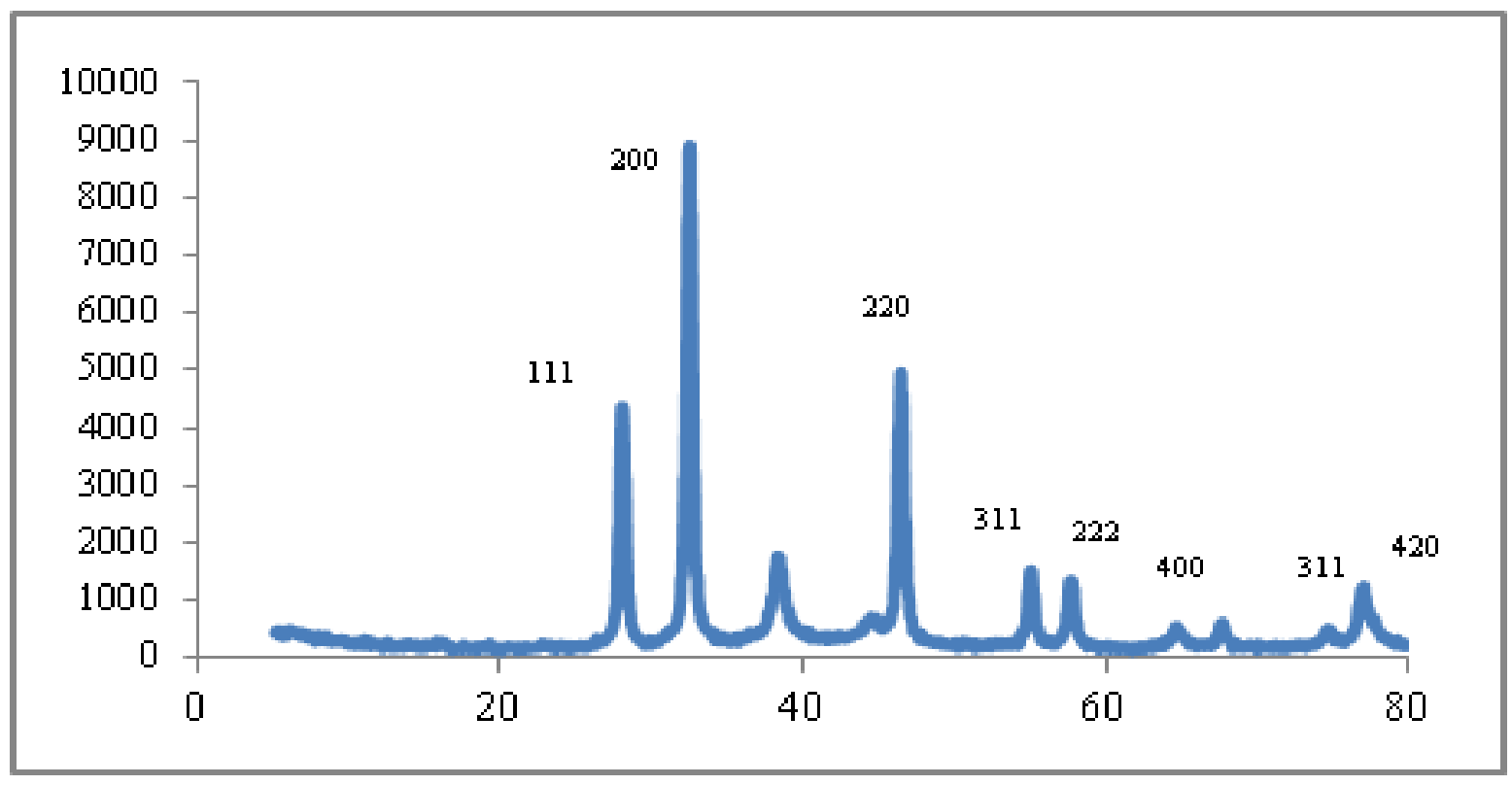

(b)

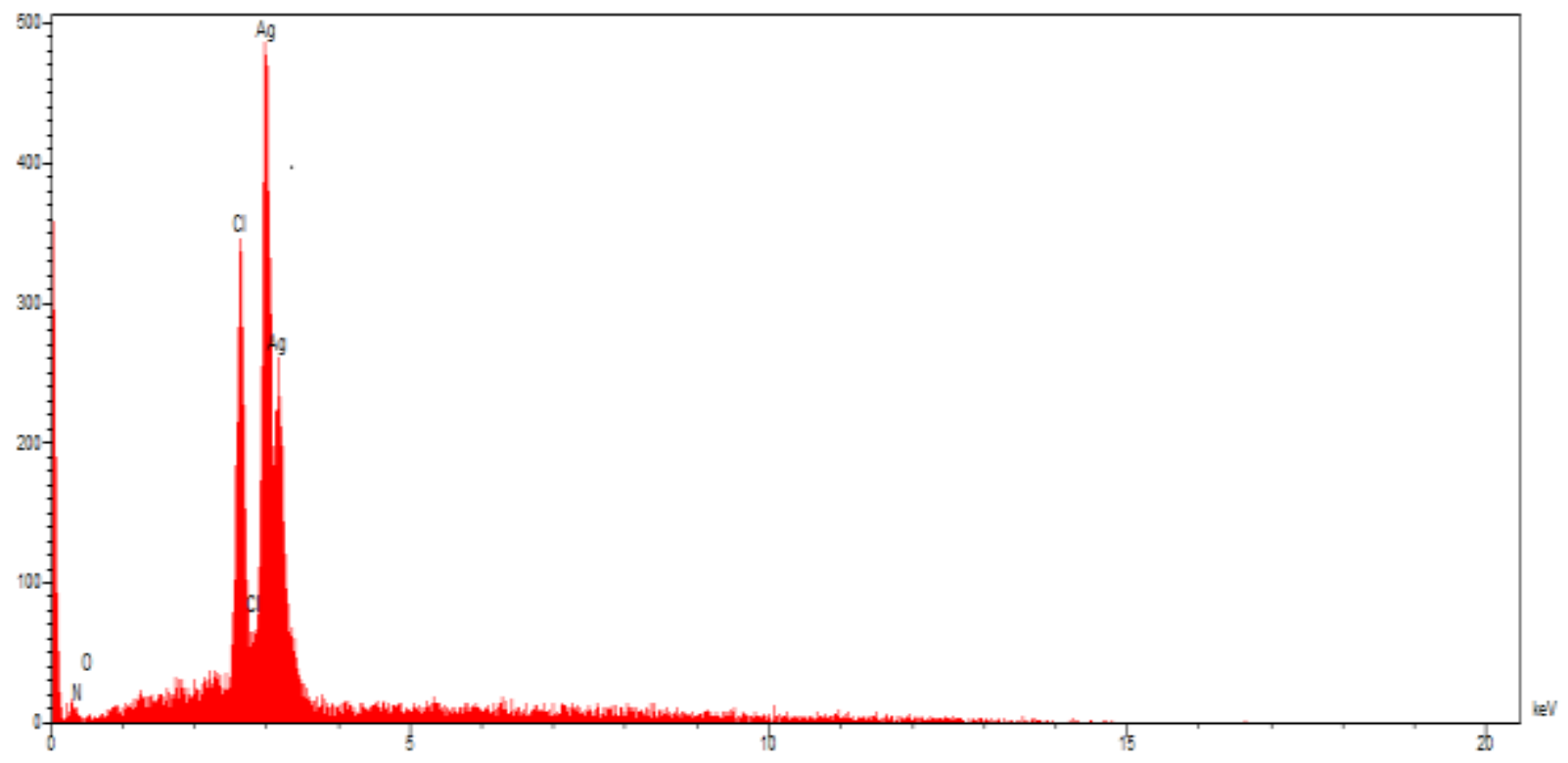

Figure 2. (a) X-ray diffraction (XRD) pattern of silver chloride nanoparticles (AgCl NPs) obtained. (b) EDAX analysis of silver chloride nanoparticle synthesized by $A$. hydrophila. 


\section{EDX Energy}

The EDX spectrum of the produced nanoparticles shows the percentage of elements in the sample relative to the total elements present (Figure 2b). EDX analysis of the produced nanoparticle displayed the presence of a high intensity absorption peak at $3 \mathrm{kV}$, in which silver constitutes $53.88 \%$ of the elements and was a proof of the presence of silver nanoparticle in the medium. The chlorine in the sample was $36.40 \%$, suggesting the presence of $\mathrm{AgCl}$ NP. Nitrogen and oxygen have $8.73 \%$ and $1.08 \%$, respectively, probably due to the release of coating proteins.

\section{FT-IR analysis of the synthesized $\mathrm{AgCl}$ NP}

The FT-IR spectra of silver nanoparticles synthesized by bacteria are also shown in Figure (4). Properties of the surface of synthesized nanoparticles were demonstrated by FTIR analysis. This helps to identify potential molecules that act as a coating and reducing agent. The bond related to each peak in these spectra is summarized in Table (1).

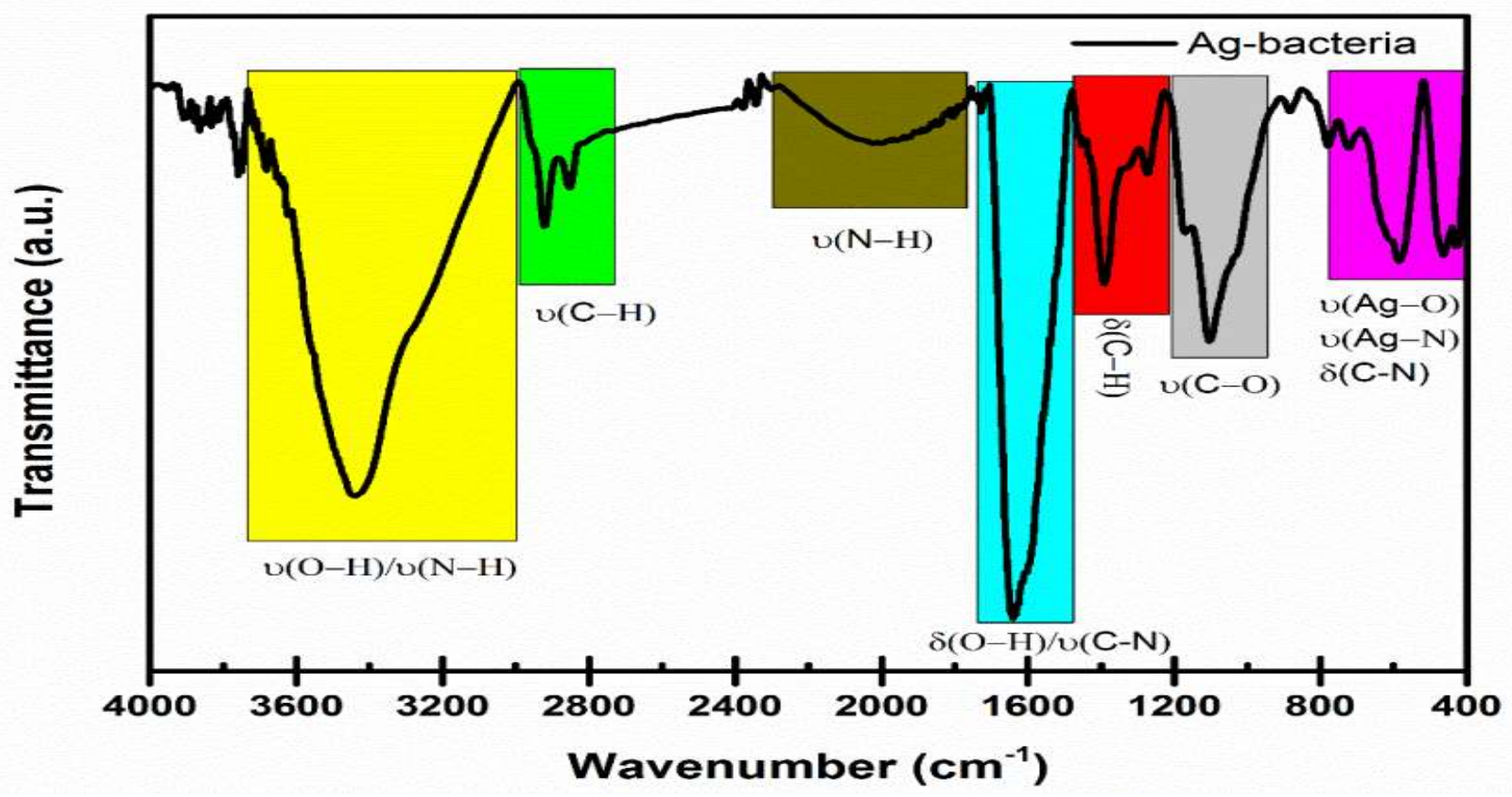

Figure 3. FTIR spectrum of silver chloride nanoparticles.

Table 1. The bonds related to each peak in the FT-IR spectrum

\begin{tabular}{llc}
\hline Resources & Bond & Wavenumber $\left(\mathrm{cm}^{-1}\right)$ \\
\hline$[26]$ & Symmetric and asymmetric stretching vibration of Ag-O and Ag-N bonds & 466 \\
{$[27]$} & Bending vibration of C-N bonds & 586 \\
{$[28]$} & Symmetric and asymmetric stretching vibration of C-O bonds & 1103 \\
{$[29,30]$} & Bending vibration of C-H bonds in $-\mathrm{CH}_{2}$ groups & 1390 \\
{$[31]$} & Bending vibration of $\mathrm{H}-\mathrm{O}$ bonds and stretching vibration of C-N bonds & 1641 \\
{$[32,33]$} & Symmetric stretching vibration of $\mathrm{C}=\mathrm{O}$ bonds & 1728 \\
{$[34]$} & Stretching vibration of N-H in primary amines & 2003 \\
{$[35,36]$} & Symmetric stretching vibration of C-H bonds & 2852 \\
{$[35,36]$} & Asymmetric stretching vibration of C-H bonds & 2919 \\
{$[37,38]$} & Stretching vibration of H-O and N-H bonds (amine type 2) & 3419 \\
\hline
\end{tabular}

According to Table (1) and Figure (3), the presence of amines type 1 and 2 as well as $\mathrm{C}-\mathrm{N}$ and $\mathrm{C}-\mathrm{H}$ bonds indicates the presence of nitrate reductase enzyme in the system. Moreover, the sharp peak found at low wavenumbers $(466 \mathrm{~cm}-1)$ indicates the stretching vibration associated with bonds containing a heavy element (which is silver here). In fact, due to the great weight of the silver element, infrared rays emitted at low energies can vibrate the oxide or nitride bonds of this element. With regard to the direct relationship between the energy of the electromagnetic radiation and the wavenumber of that radiation, the bonds containing the silver element vibrate at low wavenumbers [39]. Hence, the presence of enzyme compounds 
as a stabilizing agent on the surface of silver nanoparticles synthesized by bacteria can be proved from the FT-IR spectrum of this sample.

\section{TEM analysis of silver nanoparticles}

To examine the shape of the silver nanoparticle produced and the particle size dispersion, transmission electron microscopy was performed. Silver nanoparticles have been shown to be well dispersed and mostly spherical in shape while some nanoparticles have irregularly shaped structures. The uniformity and sphericity of the nanoparticles correspond to the shape of the SPR band in the UV-Vis spectrum. The size range of nanoparticles was between 1 and $20 \mathrm{~nm}$ and the average nanoparticle size was calculated to be $6 \mathrm{~nm}$. There are several studies in which the biological system has been applied for the synthesis of AgNP using the culture supernatant of Klebsiella Pneumoniae, B. licheniformis, E. coli and B. cereus with average sizes of $52.5,40,50$ and $10 \mathrm{~nm}$, respectively [22,40-42]. This report and previous reports, FT-IR and TEM data reveal that proteins and enzymes stabilize AgNPs and prevent their accumulation.

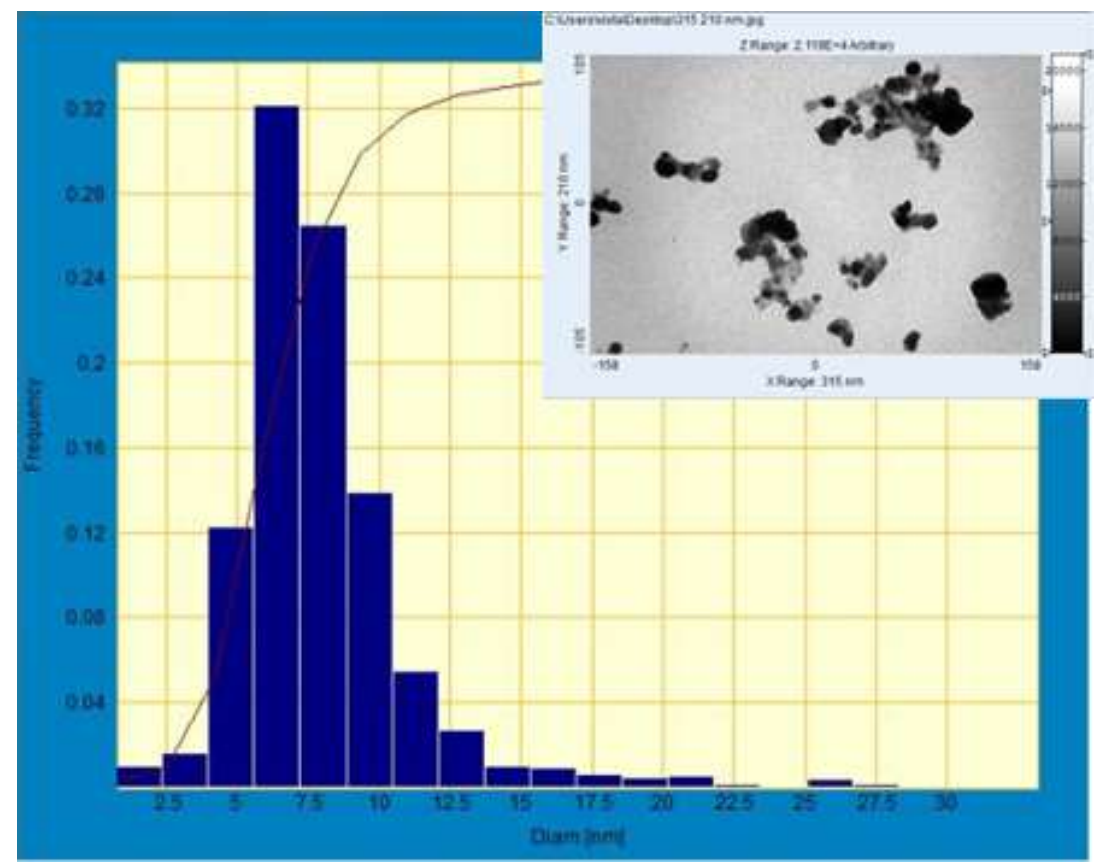

Figure 4. TEM images of AgNP indicating their spherical form. Size distribution histogram of NPs indicates $6 \mathrm{~nm}$ as dominant size.

\section{Identification of bacterial extract reducing agents}

Reducing materials are effective in making all kinds of silver nanoparticles. The concentrations of bacterial extract reducing agents have been provided in Table (2) and Figure (5). Reductase enzymes, especially $\mathrm{NADH}$-dependent enzymes such as NR, form the electron shuttle and may transfer electrons to silver ions. Reports of AgNP synthesis by bacteria in the presence of reducing agents such as NR and amino acids for AgNP synthesis by Bacillus subtilis have been presented $[14,16]$. The nitrite content of the extract was measured to determine the amount of nitrate reductase enzyme and a standard nitrite curve was drawn. The linearity of the calibration curve from 0 to $250 \mathrm{nmol} / \mathrm{ml}$ was displayed for sodium nitrite. The amount of nitrate reductase enzyme for the extract was calculated to be $54.54 \mathrm{nmol} / \mathrm{mL}$. Saifuddin and coauthors [14] in 2008, using Bacillus subtilis culture supernatant, El-Batal and coauthors [43] in 2013, using Bacillus stearothermophilus culture supernatant, and Somee et al [16] in 2018, using Bacillus cell-free extract, demonstrated that $\mathrm{NADH}$-dependent nitrate reductase enzyme is the most important factor for silver ion reduction and silver nanoparticle production [14, 16, 43]. The quantitative amount of nitrate reductase enzyme can be affected by various factors such as the number of bacteria used, the difference in the source of bacterial strains, the type of culture medium and the incubation time.

Peptides are also another factor that is very important in the construction and stability of silver nanoparticles. Peptides containing arginine, cysteine, glutamic acid, aspartic acid, lysine and methionine can reduce $\mathrm{Ag}$ ions to nanoparticles [11]. Monosaccharides are also linear at high $\mathrm{pH}$ values. The functional group of aldehydes is oxidized through reduction of silver ions and formation of silver nanoparticles [44]. 
Based on the standard BSA curve, the amount of protein was quantified and the linearity of the calibration curve was obtained to be $0-1 \mathrm{mg} / \mathrm{mL}$. The protein content of the bacterial extract was $0.56 \mathrm{mg} / \mathrm{mL}$. The results of the studies by Punjabi and coauthors estimated the total protein content of the supernatant in the range of 3-5 $\mu \mathrm{g} / \mathrm{mL}$ [45]. Besides, the standard glycine curve was plotted to measure the amino acid content and the standard glucose curve was plotted to measure the carbohydrate content. The linearity of the calibration curve was obtained from $0-100 \mu \mathrm{g} / \mathrm{mL}$ for glycine concentration and $0-80 \mathrm{mg} / \mathrm{mL}$ for glucose concentration. The amino acid and glucose levels in the bacterial extract were 87.26 and $60.46 \mathrm{mg} / \mathrm{mL}$, respectively. In this research, the extract $\mathrm{pH}$ was adjusted with $\mathrm{NaOH}$ and no chlorine ion was added to the medium to adjust the $\mathrm{pH}$. The exact mechanism of $\mathrm{AgCl} \mathrm{NP}$ synthesis is still unclear. It seems that carboxylic functional groups are confined to amino acids and are negatively charged at high $\mathrm{pH}$, so they can react with $\mathrm{Ag}$ cation and prevent its reduction by reducing the groups. In the presence of chloride and under suitable conditions for the formation of $\mathrm{AgCl}$ in colloidal form, chloride binds to $\mathrm{Ag}$ ion and forms $\mathrm{AgCL}$ nanoparticles [16, 46]. Further, linear monosaccharides are converted to the carboxylic form by reducing $\mathrm{Ag}$ ions (to produce small amounts of $\mathrm{AgNP}$ ) at alkaline $\mathrm{pH}$, and then provide a surface for $\mathrm{Ag}$ ion binding and $\mathrm{AgCl} \mathrm{NP}$ synthesis [16].

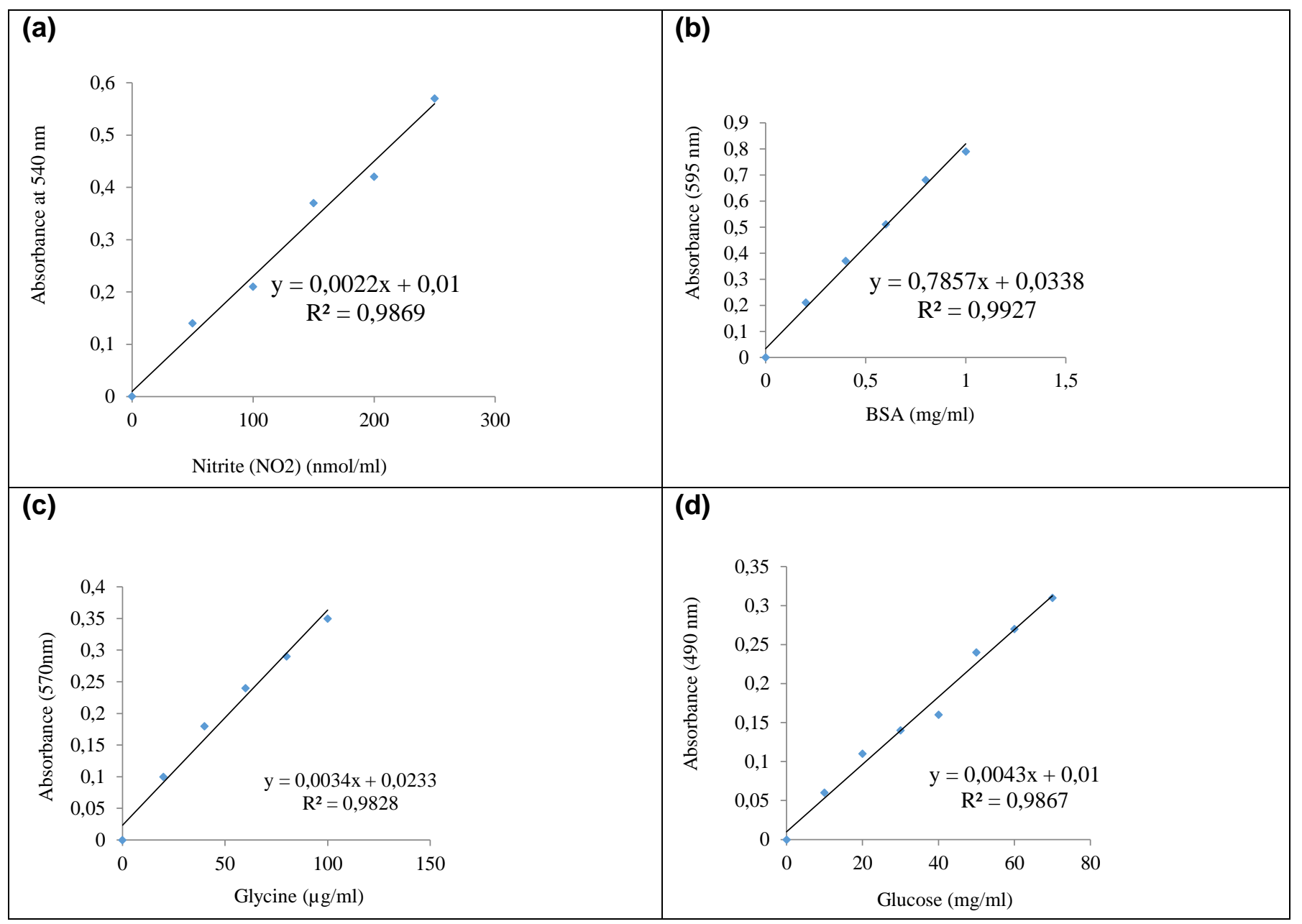

Figure 5. Standard curve of extinction against (a) Nitrite concentration $y=0.0022 x+0.01, \quad r 2=0.9869$; (b) BSA concentration $y=0.7857 x+0.0338, r 2=0.9927$; (c) Glycine concentration $y=0.0034 x+0.0233 \mathrm{r} 2=0.9828$; (d) Glucose concentration $y=0.0043 x+0.01, r 2=0.9867$

Table 2. Reducing agents in bacterial extract

\begin{tabular}{ccccc}
\hline Sample & Nitrite production by NR & Protein & Amino acid & Carbohydrate \\
\hline Bacterial extract & $54.54 \mathrm{nmol} / \mathrm{mL}$ & $0.56 \mathrm{mg} / \mathrm{mL}$ & $87.26 \mathrm{mg} / \mathrm{mL}$ & $60.46 \mathrm{mg} / \mathrm{mL}$ \\
\hline
\end{tabular}

DPPH test was performed to determine the antioxidant activity of the bacterial extract. DPPH free radical is violet and when absorbed in methanol, it has an absorption power approximately at $520 \mathrm{~nm}$ while it receives electrons from any substance, such as antioxidants, that can give electrons and its color (DPPH) changes 
from violet to yellow. Therefore, the absorption rate is reduced to $520 \mathrm{~nm}$. With increased percentage of antioxidant activity, more DPPH free radicals are converted to molecular DPPH [47]. DPPH experiments suggested that the extract and nanoparticles contain free radicals. DPPH scavenging assay compares effective inhibitory activity of nanoparticles and extract with ascorbic acid standard. The results revealed that the activity of DPPH nanoparticles increased in a dose-dependent manner. Thus, silver nanoparticles (37\%) had greater DPPH activity than plant extract $(16 \%)$ at $500 \mu \mathrm{g} / \mathrm{mL}$ (Figure 6 ).

As the results indicate, the nanoparticles had higher antioxidant activity than the extract. This suggests that the antioxidant activity of silver nanoparticles is not related to stabilizing agents but is due to the properties of the element silver although the mechanism of action of silver nanoparticles at a more precise level requires more complex experimental proof.

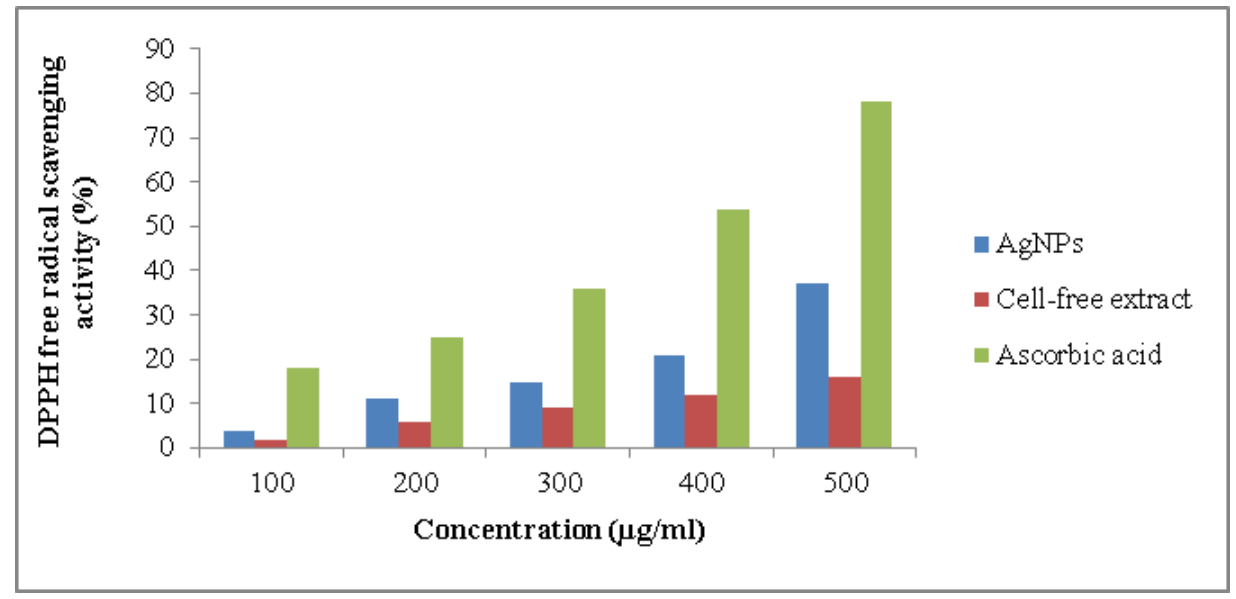

Figure 6. DPPH free radical scavenging activity of cell-free extracts of Aeromonas hydrophila and AgNPs.

\section{Study of antimicrobial effect of $\mathrm{AgCl}$ NP using well plate method}

The results demonstrated that the intensity of antibacterial activity depends on the concentration of nanoparticles. As shown in Table (3), the antibacterial effect of silver nanoparticles on E. coli and S. aureus had, respectively, $21 \pm 0.99$ and $17 \pm 2.2 \mathrm{~mm}$ diameter inhibition zones at a concentration of $100 \mu \mathrm{g} / \mathrm{mL}$. The results show that $\mathrm{E}$. coli was more sensitive to nanoparticle stress compared to $\mathrm{S}$. aureus. The lowest antibacterial activity was reported for Pseudomonas aeruginosa $(13 \mathrm{~mm})$. The mechanism of action of silver ion inhibition on microorganisms is somewhat known. It is believed that DNA loses its ability to replicate and cell proteins are inactivated by $\mathrm{Ag}+$ treatment. Moreover, it has been shown that $\mathrm{Ag}^{+}$binds to protein functional groups, thereby denaturing the protein. Previous studies have demonstrated that when $E$. coli is treated with highly reactive metal oxide nanoparticles, the bacterial membrane permeability increases, resulting in disruption of the regulatory system of transmission through the plasma membrane and ultimately cell death [48]. Previous reports indicate that nanoparticles synthesized biologically by Thermophilic Bacillus Sp. $A Z 1$ had greater antibacterial activity against E. coli. $(23 \mathrm{~mm})$ relative to $S$. aureus $(15 \mathrm{~mm})$ [48]. Additionally, using the bacterial strain of cyanobacterium Oscillatoria limnetica, inhibitory diameters of 22 and $20 \mathrm{~mm}$ have been reported, respectively, for $E$. coli and B. cereus in the green synthesis of silver nanoparticles [49].

\section{Study of the effect of the produced nanoparticle on bacterial growth inhibition using microdilution method (MIC)}

The results suggest that the control sample has turbidity and with increasing the concentration of nanoparticles, the bacterium growth rate decreases. MIC values for Staphylococcus aureus, Escherichia coli, Pseudomonas aeruginosa and Bacillus subtilis were presented in Table (3). Growth of E. coli and S. aureus with concentrations of 12.5 and $25 \mu \mathrm{g} / \mathrm{mL}$, respectively, was reported as minimum inhibition concentration (MIC). Pseudomonas aeruginosa and Bacillus subtilis had a MIC of $50 \mu \mathrm{g} / \mathrm{mL}$. These results show that silver nanoparticles have an antibacterial effect by delaying the growth of bacteria. Gopinath and coauthors [50] synthesized silver nanoparticles using Pseudomonas putida bacterial extract and investigated its antibacterial effect on standard strains of Staphylococcus aureus, Escherichia coli, Bacillus cereus and Pseudomonas aeruginosa by well plate and MIC methods. Based on the obtained results, silver nanoparticles were not toxic to bacterial growth at concentrations less than $25 \mu \mathrm{g} / \mathrm{mL}$. Different responses of bacterial strains to 
biosynthetic silver nanoparticles in different reports may be due to different factors, such as the number of colony-forming units (CFUs) used in each bacterial sample, the difference in the source of bacterial strains, the precursor used to synthesize silver nanoparticles, the use of different reducing and coating agents and difference in size and shape of silver nanoparticles [51, 52].

Table 3. Zone of inhibition and MIC of Ag NPs against Staphylococcus aureus (ATCC 25923), Bacillus subtilis (ATCC 6633), Escherichia coli (ATCC 25922) and Pseudomonas aeruginosa (ATCC 27853)

\begin{tabular}{|c|c|c|c|c|c|c|}
\hline \multirow[t]{2}{*}{ Bacteria } & \multicolumn{5}{|c|}{ Diameter of inhibition zone $(\mathrm{mm}) \pm S D$} & \multirow[t]{2}{*}{$\mathrm{NP} \mathrm{MIC}, \mu \mathrm{g} / \mathrm{mL}$} \\
\hline & $100 \mu \mathrm{g} / \mathrm{mL}$ & $50 \mu \mathrm{g} / \mathrm{mL}$ & $25 \mu \mathrm{g} / \mathrm{mL}$ & $12.5 \mu \mathrm{g} / \mathrm{mL}$ & $6.25 \mu \mathrm{g} / \mathrm{mL}$ & \\
\hline Staphylococcus aureus & $17 \pm 2.2$ & $17 \pm 1.6$ & $16 \pm 1.1$ & $15 \pm 0.99$ & $14 \pm 1.7$ & 12.5 \\
\hline Bacillus subtilis & $15 \pm 1.8$ & $15 \pm 2.2$ & $11 \pm 1.3$ & LG & LG & 50 \\
\hline Escherichia coli & $21 \pm 0.99$ & $17 \pm 2.1$ & $16 \pm 1.1$ & $16 \pm 1.5$ & $12 \pm 2.2$ & 25 \\
\hline Pseudomonas aeruginosa & $13 \pm 1.2$ & $13 \pm 1.9$ & $10 \pm 1.1$ & LG & LG & 50 \\
\hline
\end{tabular}

LG: lack of growth; SD: standard deviation

\section{Cell viability assay in silver nanoparticles}

Today, the biological role of silver nanoparticles in the diagnosis and treatment of human cancers has received much attention. In this study, the cytotoxicity of silver nanoparticles against two human cancer cell lines (MCF-7 breast cancer and HepG-2 liver cancer) was investigated in vitro using MTT assay. Nanoparticles displayed a cytotoxic effect against MCF-7 and HepG-2 cells as a dose-dependent reaction with different concentrations $(0,3.15,6.25,12.5,25,50,100 \mu \mathrm{g} / \mathrm{mL}$ ) while cytotoxic action (IC50) was 10.6 and $10.4 \mu \mathrm{g} / \mathrm{mL}$, respectively, in 24-hour and 48-hour culture of HepG-2 cells and 34.4 and $18.7 \mu \mathrm{g} / \mathrm{mL}$ in MCF-7 (Figure 7). As a result, silver nanoparticles showed stronger cytotoxic action against HepG-2 than MCF-7 cells. Silver nanoparticles penetrate mammalian cells through phagocytosis or endocytosis, which significantly depends on the size of nanoparticles. Many attempts have been made to clarify the mechanism of the cytotoxic effect of nanoparticles through the production of free radicals, which cause cell disintegration and ultimately cell death. ROS production and oxidative stress are two possible mechanisms of the cytotoxic effects of nanoparticles on eukaryotic cells. Rahman and coauthors [53] proposed that nanoparticles often absorb available free electrons and thus increase the synthesis of reactive oxygen species (ROS). As a result of this increase in the synthesis, harmful radicals attack the protein and cause oxidative stress, which leads to partial or permanent damage to the integrity and function of the protein. It was also found that nanoparticles regulate DNA-dependent kinase activity in repairing DNA damage [54]. Different sensitivities of breast cancer cells to silver nanoparticles cause hyperthermia by which nanoparticles can act as a successful treatment [55]. The current results are consistent with the findings obtained by Ranijithan and coauthors [56] and Hamouda and coauthors [49]. They reported that the cytotoxic effect identified against MCF-7 cells with different concentrations of nanoparticles is positively dose-dependent. 
(a)

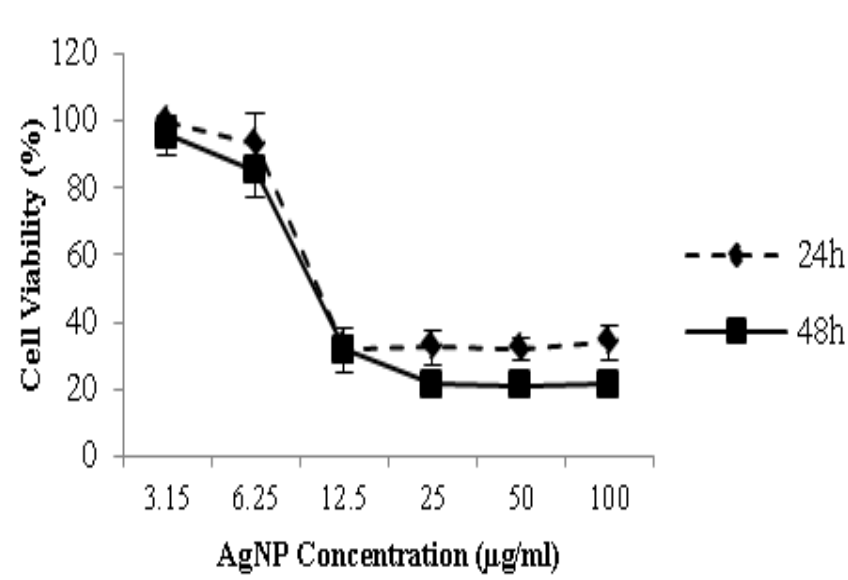

(b)

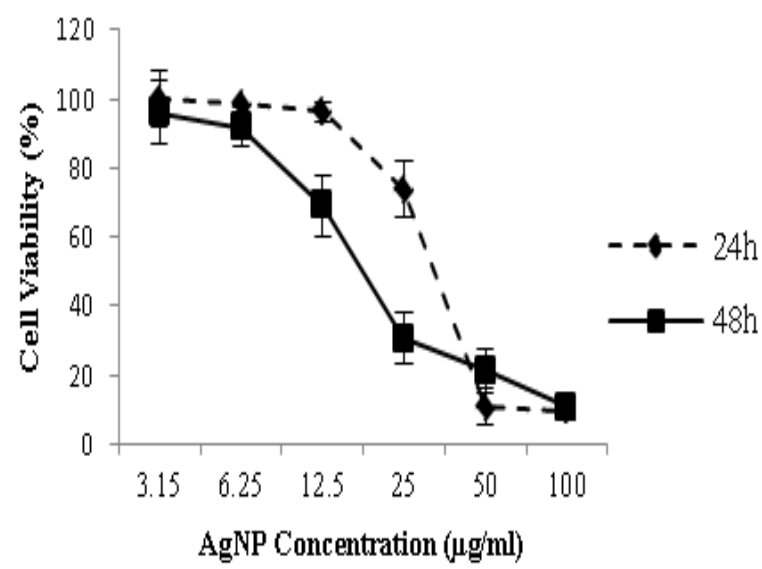

Figure 7. In vitro cytotoxicity assay for $\mathrm{AgCl} \mathrm{NP}$; (a) Viability of MCF-7 cells exposed to $\mathrm{AgCl} \mathrm{NP}$; (b) Cell viability of HepG-2 cells exposed to various concentrations of AgNP.

\section{CONCLUSION}

In this study, silver nanoparticles were synthesized using the cell-free extract of Aeromonas hydrophila and the effect of various biochemical factors on the synthesis was investigated. The main difference between the present research and previous studies is the use of bacterial cell-free extracts for the synthesis of nanoparticles. The results revealed that the bacterial cell-free extracts produce stable silver nanoparticles by reducing $\mathrm{Ag}^{+}$ions to AgNP ions. Further, the bacterial extract contains stabilizing compounds such as proteins and carbohydrates that are able to provide a stable colloidal space for silver chloride nanoparticles. The biological approach to AgNP synthesis has numerous benefits including non-toxicity, high efficiency, rapid reduction and cost-effectiveness. Future perspectives of this research are large-scale production of nanoparticles using $A$. hydrophila cell-free extract and evaluation of its effectiveness against a wide range of microbial populations.

Acknowledgement: The authors wish to appreciate Graduate School of Ferdowsi University for providing necessary facilities to carry out this work.

Finding: This study is based on the Ph.D. thesis of Bacteriology. It was performed by the Department of Pathobiology, Faculty of Veterinary Medicine, Ferdowsi University of Mashhad (Grant Code No.:46373). All the materials and equipment required in this study were provided by the Ferdowsi University of Mashhad.

Disclosure statement: No potential conflict of interest was reported by the authors.

\section{REFERENCES}

1. De Jong WH, Borm PJ. Drug delivery and nanoparticles: applications and hazards. Int. J. Nanomedicine. 2008;3(2):133.

2. Tan $M$, Guilan $W$, Zhiqiang $Y$, Jingli $Y$. Synthesis and characterization of titania-based monodisperse fluorescent europium nanoparticles for biolabeling. J. Lumin. 2006; 117(1):20-8.

3. Berendonk TU, Manaia CM, Merlin $\mathrm{CH}$. Tackling antibiotic resistance: the environmental framework. Nat. Rev. Microbiol. 2015;13(5):310-7.

4. Ramezani M. Biosynthesis of metal nanoparticles by micro-organisms. Nanocon Olomouc, Czech Republic, EU. 2010;10:12-8.

5. Zhang $\mathrm{X}$, Yan S, Tyagi RD, Surampalli RY. Synthesis of nanoparticles by microorganisms and their application in enhancing microbiological reaction rates. Chemosphere. 2011;82(4):489-94.

6. Jain N, Bhargava A, Majumdar S, Tarafdar J, Panwar J. Extracellular biosynthesis and characterization of silver nanoparticles using Aspergillus flavus NJP08: a mechanism perspective. Nanoscale $2011 ; 3(2): 635-41$.

7. Kalimuthu K, Babu RS, Venkataraman D, Bilal M, Gurunathan S. Biosynthesis of silver nanocrystals by Bacillus licheniformis. Colloids Surf B Biointerfaces 2008;65(1):150-3. 
8. Das VL, Thomas R, Varghese RT, Soniya E, Mathew J, Radhakrishnan E. Extracellular synthesis of silver nanoparticles by the Bacillus strain CS 11 isolated from industrialized area. 3 Biotech 2014;4(2):121-6.

9. Kushwaha A, Singh VK, Bhartariya J, Singh P, Yasmeen K. Isolation and identification of E. coli bacteria for the synthesis of silver nanoparticles: characterization of the particles and study of antibacterial activity. Eur J Exp Biol 2015;5(1):65-70.

10. Singh P, Singh H, Kim YJ, Mathiyalagan R, Wang C, Yang DC. Extracellular synthesis of silver and gold nanoparticles by Sporosarcina koreensis DC4 and their biological applications. Enzyme Microb Technol 2016;86:75-83.

11. Singh R, Shedbalkar UU, Wadhwani SA, Chopade BA. Bacteriagenic silver nanoparticles: synthesis, mechanism, and applications. Appl. Microbiol. Biotechnol. 2015; 99(11): 4579-93.

12. Boulc'h F, Schouler MC, Donnadieu P, Chaix JM, Djurado E. Domain size distribution of Y-TZP nanoparticles using XRD and HRTEM. Image Anal. Stereol. 2001;20(3):157-61.

13. Harley SM. Use of a simple, colorimetric assay to demonstrate conditions for induction of nitrate reductase in plants. Am Biol Teach, 1993.55(3):161-4.

14. Saifuddin N, Wong C, Yasumira A. Rapid biosynthesis of silver nanoparticles using culture supernatant of bacteria with microwave irradiation. J.Chem. 2009.6(1):61-70.

15. Kruger $\mathrm{NJ}$, The Bradford method for protein quantitation, in The protein protocols handbook. 2009.Springer.17-24.

16. Somee LR, Ghadam P, Abdi-Ali A, Fallah S, Panahi Gh. Biosynthesised AgCl NPs using Bacillus sp. $1 / 11$ and evaluation of their cytotoxic activity and antibacterial and antibiofilm effects on multi-drug resistant bacteria. IET Nanobiotechnol. 2018.12(6):764-72.

17. Albalasmeh AA, Berhe AA, Ghezzehei TA. A new method for rapid determination of carbohydrate and total carbon concentrations using UV spectrophotometry. Carbohydr. Polym. 2013.97(2):253-61.

18. Maizura M, Aminah A, Wan Aida WM. Total phenolic content and antioxidant activity of kesum (Polygonum minus), ginger (Zingiber officinale) and turmeric (Curcuma longa) extract. Int. Food Res. J. 2011.18(2):529-34.

19. Sriram MI, Kalishwaralal K, Barathmanikanth S, Gurunathani S. Size-based cytotoxicity of silver nanoparticles in bovine retinal endothelial cells. Nanoscience Methods. 2012.1(1):56-77.

20. Boopathi S, Gopinath S, Boopathi Th, Balamurugan V, Rajeshkumar R, Sundararaman M. Characterization and antimicrobial properties of silver and silver oxide nanoparticles synthesized by cellfree extract of a mangrove-associated Pseudomonas aeruginosa M6 using two different thermal treatments. Ind. Eng. Chem. Res. 2012.51(17):5976-85.

21. Khatami, M, Pourseyedi S. Phoenix dactylifera (date palm) pit aqueous extract mediated novel route for synthesis high stable silver nanoparticles with high antifungal and antibacterial activity. IET Nanobiotechnol. 2015.9(4):184-90.

22. Gurunathan S, Raman J, Abd Malek SN, John PA, Vikineswary S. Green synthesis of silver nanoparticles using Ganoderma neo-japonicum Imazeki: a potential cytotoxic agent against breast cancer cells. Int $\mathrm{J}$ Nanomedicine. 2013.8:4399.

23. Kelly KL, Coronado E, Zhao LL, Schatz G. The optical properties of metal nanoparticles: the influence of size, shape, and dielectric environment. J.Phys.Chem.B. 2003.107(3):668-77.

24. John MS, Nagoth JA, Ramasamy KP, Mancini A, Giuli G, Natalello A, et al. Synthesis of Bioactive Silver Nanoparticles by a Pseudomonas Strain Associated with the Antarctic Psychrophilic Protozoon Euplotes focardii. Mar.Drugs. 2020. 18(1):38.

25. Paulkumar K, Rajeshkumar Sh, Gnanajobitha G, Vanaja M, Malarkodi Ch, Annadurai G. Biosynthesis of silver chloride nanoparticles using Bacillus subtilis MTCC 3053 and assessment of its antifungal activity. Int Sch Res Notices. 2013.1-8.

26. Asiri AM, Khan ShB, Rahman MM, Al-Sehemi AG, Al-Sayari SA, Al-Assiri MS. Green material: ecological importance of imperative and sensitive chemi-sensor based on $\mathrm{Ag} / \mathrm{Ag} 2 \mathrm{O} 3 / \mathrm{ZnO}$ composite nanorods. Nanoscale Res. Lett. 2013. 8(1):1-8.

27. Ghaedi M, Yousefinejad M, Safarpoor M, Khafri HZ, Purkait MK. Rosmarinus officinalis leaf extract mediated green synthesis of silver nanoparticles and investigation of its antimicrobial properties. $J$ Ind Eng Chem. 2015.31:167-72.

28. Zheng H, Shao Y, Wang Y, Meng G, Liu B. Reinforcing the corrosion protection property of epoxy coating by using graphene oxide-poly (urea-formaldehyde) composites. Corros. Sci. 2017.123:267-77. 
29. Jung M.R, Horgen FD, Orski SV, Rodriguez V, Beers KL, Balazs GH, Jones TT, et al. Validation of ATR FT-IR to identify polymers of plastic marine debris, including those ingested by marine organisms. Mar. Pollut. Bull. 2018.127:704-16.

30. Chen W, He H, Zhu H, Cheng M, Li Y, Wang Sh. Thermo-responsive cellulose-based material with switchable wettability for controllable oil/water separation. Polymers. 2018.10(6):p.592.

31. Kayalvizhi T, Ravikumar S, Venkatachalam P. Green synthesis of metallic silver nanoparticles using Curculigo orchioides rhizome extracts and evaluation of its antibacterial, larvicidal, and anticancer activity. J Environ Eng (New York). 2016.142(9).

32. Ramesh, S., Wang J, Patterson TA, Saini UT, Robinson BL, Newport GD, et al. FTIR studies of PVC/PMMA blend based polymer electrolytes. Spectrochim. Acta A Mol. Biomol. Spectrosc. 2007.66(45):1237-42.

33. Prabu K, Natarajan E. Isolation and FTIR spectroscopy characterization of chitin from local sources. Adv. Appl. Sci. Res. 2012.3(2):1870-5.

34. Nikpour B, Ramezanzadeh B, Bahlakeh Gh, Mahdavian M. Synthesis of graphene oxide nanosheets functionalized by green corrosion inhibitive compounds to fabricate a protective system. Corros. Sci. 2017.127:240-59.

35. Parhizkar N, Shahrabi T, Ramezanzadeh B. Steel surface pre-treated by an advance and eco-friendly cerium oxide nanofilm modified by graphene oxide nanosheets; electrochemical and adhesion measurements. J. Alloys Compd. 2018.747:109-23.

36. Khankrua R, Pongpanit T, Paneetjit P, Boonmark R, Seadan M, Suttiruengwong S. Development of PLA/EVA Reactive Blends for Heat-Shrinkable Film. Polymers. 2019.11(12):1925.

37. Javidparvar AA, Naderi R, Ramezanzadeh B, Bahlakeh Gh. Graphene oxide as a pH-sensitive carrier for targeted delivery of eco-friendly corrosion inhibitors in chloride solution: Experimental and theroretical investigations. J Ind Eng Chem. 2019.72:196-213.

38. Javidparvar AA, Naderi R, Ramezanzadeh B. L-cysteine reduced/functionalized graphene oxide application as a smart/control release nanocarrier of sustainable cerium ions for epoxy coating anti-corrosion properties improvement. J. Hazard. Mater. 2020.389:122135.

39. Khalil MM, Ismail EH, El-Baghdady KhZ, Mohamed D. Green synthesis of silver nanoparticles using olive leaf extract and its antibacterial activity. Arab. J. Chem. 2014.7(6):1131-9.

40. Shahverdi AR, Fakhimi A, Shahverdi HR, Minaian S. Synthesis and effect of silver nanoparticles on the antibacterial activity of different antibiotics against Staphylococcus aureus and Escherichia coli. Nanomedicine. 2007.3(2):168-71.

41. Kalimuthu K, Babu RS, Venkataraman D, Bilal M, Gurunathan S. Biosynthesis of silver nanocrystals by Bacillus licheniformis. Colloids Surf. B. 2008.65(1):150-3.

42. Gurunathan S. Rapid biological synthesis of silver nanoparticles and their enhanced antibacterial effects against Escherichia fergusonii and Streptococcus mutans. Arab. J. Chem. 2019.12(2):168-80.

43. El-Batal A, Amin MA, Shehata MM, Hallol MM. Synthesis of silver nanoparticles by Bacillus stearothermophilus using gamma radiation and their antimicrobial activity. World Appl Sci J. 2013.22(1):1-16.

44. Sintubin L, De Windt W, Dick J, Mast J, Van Der Ha D, Verstraete W, Boon N. Lactic acid bacteria as reducing and capping agent for the fast and efficient production of silver nanoparticles. Appl. Microbiol. Biotechnol. 2009.84(4):741-9.

45. Punjabi K, Mehta Sh, Yedurkar S, Jain R, Mukherjee S, Kale A, Deshpande S. Extracellular synthesis of silver nanoparticle by Pseudomonas hibiscicola-Mechanistic approach. Adv. Nan. Res. 2018.6(1):81.

46. Abbasi AR, Morsali A. Formation of silver iodide nanoparticles on silk fiber by means of ultrasonic irradiation. Ultrason Sonochem. 2010.17(4):704-10.

47. Dipankar C. Murugan S. The green synthesis, characterization and evaluation of the biological activities of silver nanoparticles synthesized from Iresine herbstii leaf aqueous extracts. Colloids Surf. B. 2012. 98: 112-9. 
48. El-Shanshoury AERR, EISilk SE, Ebeid ME. Extracellular biosynthesis of silver nanoparticles using Escherichia coli ATCC 8739, Bacillus subtilis ATCC 6633, and Streptococcus thermophilus ESh1 and their antimicrobial activities. ISRN Nanomater. 2011.

49. Hamouda RA, Hussein MH, Abo-elmagd RA, Bawazir SS. Synthesis and biological characterization of silver nanoparticles derived from the cyanobacterium Oscillatoria limnetica. Sci. Rep. 2019. 9(1): 1-17.

50. GopinathV, Priyadarshini S, Loke MF, Arunkumar J, Marsili E, MubarakAli D, Velusamy P, et al. Biogenic synthesis, characterization of antibacterial silver nanoparticles and its cell cytotoxicity. Arab. J. Chem. 2017.10(8):1107-17.

51. Ashokkumar S, Ravi S, Kathiravan V, Velmurugan S. Synthesis of silver nanoparticles using A. indicum leaf extract and their antibacterial activity. 2015.134:34-9.

52. Chahardoli A, Karimi N, Fattahi A. Biosynthesis, characterization, antimicrobial and cytotoxic effects of silver nanoparticles using Nigella arvensis seed extract. Iran J Pharm Res. 2017.16(3):1167.

53. Rahman M, Wang J, Patterson TA, Saini UT, Robinson BL, Newport GD, et al. Expression of genes related to oxidative stress in the mouse brain after exposure to silver-25 nanoparticles. Toxicol. Lett. 2009.187(1):15-21.

54. Dos Santos CA, Dos Santos CA, Seckler MM, Ingle AP, Gupta I, Galdiero S, et al. Silver nanoparticles: therapeutical uses, toxicity, and safety issues. J. Pharm. Sci. 2014. 103(7):1931-44.

55. Thompson EA, Graham E, MacNeill ChM, Young M, Donati G, Wailes EM, et al. Differential response of MCF7, MDA-MB-231, and MCF 10A cells to hyperthermia, silver nanoparticles and silver nanoparticleinduced photothermal therapy. Int J Hyperthermia. 2014.30(5):312-23.

56. Ranjitham AM, Suja R, Caroling G, Tiwari S. In vitro evaluation of antioxidant, antimicrobial, anticancer activities and characterisation of Brassica oleracea. var. Bortrytis. L synthesized silver nanoparticles. Int J Pharm Pharm Sci. 2013.5(4):239-51.

2021 by the authors. Submitted for possible open access publication under the terms and conditions of the Creative Commons Attribution (CC BY NC) license (https://creativecommons.org/licenses/by-nc/4.0/). 